\title{
SYSTEMIC HUMORAL FACTORS PARTICIPATING IN THE COURSE OF SPINAL CORD INJURY
}

\author{
By Y. Mizrachi, ${ }^{1}$ A. Ohry, M.D., ${ }^{2}$ A. Aviel, M.D., R. Rozin, M.D., ${ }^{2}$ M. \\ E. Brooks, M.D. ${ }^{2}$ and M. SchwarTz, Ph.D. ${ }^{1}$ \\ ${ }^{1}$ Department of Neurobiology, The Weizmann Institute of Science, Rehovot, Israel. \\ ${ }^{2}$ The Neurological Rehabilitation Department, The Chaim Sheba Medical Centre, \\ Tel HaShomer and Sackler School of Medicine, Tel Aviv University, Israel
}

Summary. Systemic humoral factors have been studied in traumatic, chronic and acute spinal cord injured patients. Antibodies specific to nervous system autoantigens were detected in a majority of the sera obtained from these patients, at different periods after injury. Limited in vitro sprouting of dorsal root ganglia in chicken embryos was observed in the presence of serum from these patients. The possible association between growth inhibiting factors and the presence of antibodies against nervous tissue autoantigens is discussed.

Key words: Spinal cord injury; Systemic humoral factors.

\section{Introduction}

REGENERATION IN the transected spinal cord or nerve tracts proceeds only for short distances and lasts about 2 weeks before stopping without further growth (De La Torre, I98I). Several obstacles have been considered for the limited regenerative capacity, amongst which are diffusible factors including immune factors (Berry and Riches, I974).

Various substances that have trophic qualities (Varon and Adler, I98I) with probably distinct specificity are contributing to the complete recovery of an injured nerve. A prototype substance is the nerve growth factor (NGF) (Levi-Montalcini and Hamburger, I95 I, I953).

It is conceivable that due to the neuronal injury the ability of the serum to provide trophic substances is changing. Such changes could be the result of myelin breakdown which in turn can introduce inhibitory components or induce production of such inhibitory elements. It is also possible that the degenerative process causes a deficiency in cells providing trophic substances.

In the present study attempts have been made to investigate the relevance of the humoral changes to the deficiency of the spinal cord injured patients to support recovery. The results indicate that 86 per cent of the patients examined developed in their sera antibodies to myelin constituents including myelin basic protein (MBP) and brain gangliosides while in so called normal individuals only 32 per cent expressed in the sera antibodies with these specificities. Furthermore, the ability of the patients' sera to provide trophic effect for sprouting as was examined by the growth from cultured chick dorsal root ganglia was markedly reduced. Thus while normal human sera support outgrowth (Aviel and Schwartz, in press), 80 per cent of the patients who have experienced traumatic spinal cord injury have very limited sprouting inducing capacity. 
The association between the low sprouting activity in the sera, the immune response to the injury and the limited regenerative capacity are discussed.

\section{Materials and Methods}

\section{A. Patients}

Sera from 44 traumatic spinal cord injured patients (I 8-60 years old) of both sexes were taken at various stages following the injury. The spinal cord injuries were of variable location and severity. During the study period, none of the patients received corticosteroid therapy or suffered from a concomitant disease. Sera from 26 healthy donors and hospital staff aged 20-50 years were used as a control group.

\section{B. Solid Phase Radioimmunoassay}

The assay was performed basically as described by Schwartz et al. (1978). The wells of the microtiter plates were coated with either CNS myelin basic protein, mixed gangliosides or peripheral nerve myelin basic protein solutions ( $100 \mu \mathrm{l}$, IOO $\mu \mathrm{g}$ protein $/ \mathrm{ml}, 2 \mathrm{hrs}$ at room temperature). Following the coating the wells were washed with phospate buffer saline (PBS) containing I per cent bovine serum albumin (BSA). Thereafter the wells were incubated for $2 \mathrm{hr}$ at room temperature with Io० $\mu \mathrm{l}$ of the various sera diluted to I:IO in PBS containing I per cent BSA. Following the last incubation the wells were further incubated with iodinated goat anti-human IgG molecules (About $\mathrm{I} 80000 \mathrm{cpm}$ per well) overnight at $4^{\circ} \mathrm{C}$. The wells were then washed, cut and counted. The results are expressed by the cpm of bound ${ }^{125}$ I-goat anti-human IgG molecules.

\section{Materials}

Iodination of goat anti-human IgG was done by chlormine-T method (Hunter, 1973).

Bovine CNS myelin basic protein was prepared according to Hirshfeld et al. (1970).

Gangliosides were extracted by chloroform-methanol, followed by alkaline treatment and phase partition as previously described (Den et al., 1974) and were further purified by chromatography on DEAE-Sephadex column by elution with chloroform: methanol $-0.8 \mathrm{M}$ sodium acetate $(30: 60: 8)$ as reported by Ando and $\mathrm{Yu}$ (1977). The purified gangliosides were devoid of any phospholipid contaminants and no traces of proteins could be detected by amino acid analysis. The gangliosides contained a mixture of $\mathrm{GM}_{\mathrm{I}}$ I 2 per cent, $\mathrm{GD}_{\mathrm{Ia}} 39$ per cent, $\mathrm{GD}_{\mathrm{Ib}} \mathrm{I} 7$ per cent, $\mathrm{GT}_{\mathrm{Ib}} 25$ per cent and trace amounts of $\mathrm{GQ}_{\mathrm{rb}}, \mathrm{GD}_{2}$ and $\mathrm{GD}_{3}$.

\section{Effect of sera on sprouting from chick embryo DRG}

Chick embryo DRG (8-9 days old) were cultured in poly-L-lysine coated wells containing Dulbecco-MEM. To each well sera from either normal or spinal cord injured patients were added at the appropriate dilution. 


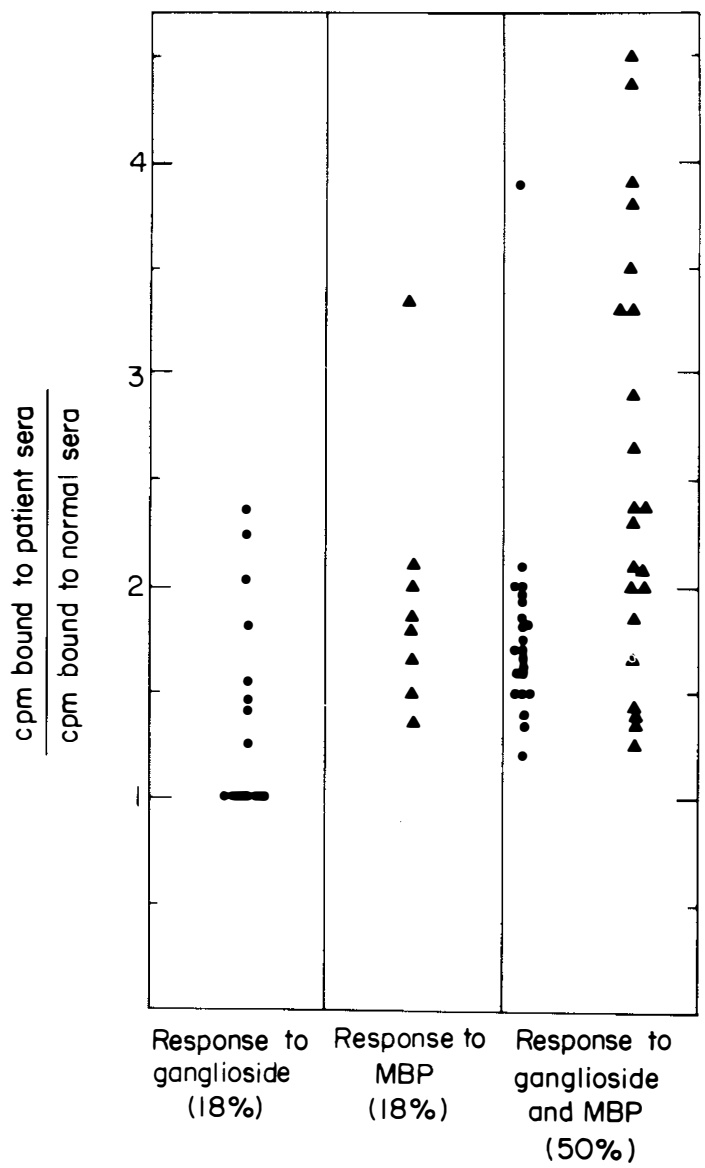

FIG. I

Antibody response to myelin basic protein $(\boldsymbol{\Delta})$ and to mixed gangliosides $(\boldsymbol{O})$ in spinal cord injured patients.

The results are expressed according to the following ratio: ${ }^{125} \mathrm{I}$-goat anti-human Ig bound to patient sera. ${ }^{125}$ I-goat anti-human Ig bound to normal sera. (average of 4 individuals)

Note: The first column demonstrates the patients responding to gangliosides only ( 18 per cent), the second column patients responding to MBP only ( 18 per cent) and the third one patients responding to the two tested antigens. The percentage was calculated from the total number of patients tested.

Neuritic outgrowth was scored 24 hours following the culturing as was described recently (Aviel and Schwartz, in press).

\section{Results}

\section{A. Antibody response to myelin constitutents}

Samples of blood were taken from 44 traumatic spinal cord injured patients. Most of them had sustained the injury a relatively long period before the blood samples were taken. 
Humoral response to specific myelin basic protein (MBP) and brain gangliosides were detected in 86 per cent of the patients (Fig. I). About I 8 per cent of the spinal cord injured patients tested exhibited humoral response only specific to gangliosides, while I 8 per cent demonstrated antibody response only to basic protein. Titration of antibody levels in the blood samples was done by the solid phase radioimmunoassay in which iodinated goat anti-human or iodianated protein-A were used. In most of the experiments goat anit-human Ig antibodies were used. Basic protein was the major proteinaceous antigenic determinant against which antibodies were elicited in the spinal cord injured patients (Fig. 2). Thus titration with MBP revealed higher titre than titration with crude extract of myelin free of lipids. No correlation was found between the antibody levels and patients' age, sex, severity of injury or duration of the disease. It should be noted that under the same conditions of titration 32 per cent of the sera obtained from normal individuals (26) demonstrated similar antibody activities (data not shown).

\section{B. Limited sprouting inducing activity in sera of spinal cord injured patients}

It has been demonstrated recently that human sera from non-injured patients contain components that can induce sprouting, in vitro, from chick embryo DRG (Aviel and Schwartz, in press). This sprouting is detected without any addition of exogenous factors. Under the same experimental conditions sera from 20 patients were tested. Eight per cent of these sera did not induce sprouting or to a very limited extent, whereas only 20 per cent of the spinal cord injured sera induced sprouting similar to that of the control group (Fig. 3).

\section{Discussion}

Thus far no cure for CNS injured patients is available. The chronic phase of spinal cord injury indicates the need to reverse a stable cytochemical condition after injury to the spinal cord (De La Torre, I98I; McDonald, 1975). The area of research that shows the most promise in chronic spinal cord damage is undoubtedly the study of regeneration of CNS tissue.

There is presumably only one way to treat a stabilised chronic spinal cord injury and that is through regeneration of the damaged neuronal cord tissue. It is assumed now that central nerve regeneration is functionally possible but that it is limited as a result of extrinsic factors. Since diffusible factors are very likely to circulate within the blood system, we have tested, in the present study, the type of humoral changes occurring following the spinal cord injury and which might exert some effect on the subsequent capability to recover as has been speculated recently (Kiernan, I979).

We have found that antibodies against several myelin antigenic determinants are produced in the spinal cord injured patients which remain in the sera for years following the injury. Production of antibodies against autoantigens have been found in other patients experiencing neuronal disorders of varous types (Caspary and Chambers, 1970; Cook and Dowling, I98I; Aviel et al., in press) as well as in experimental peripheral nerve injury in animals (Schwartz et al., I982). 


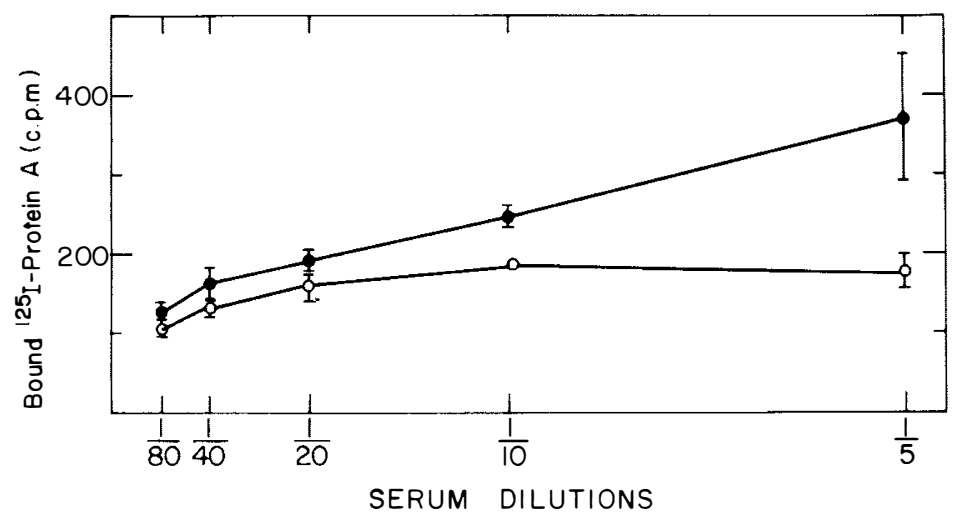

FIG. 2

Binding of serum from paraplegic patient to myelin proteins. 0 , myelin protein, crude extract; and $\bullet$, myelin basic protein, purified. The results demonstrate the binding of ${ }^{125}$ I-protein $\mathrm{A}$ in cpm.

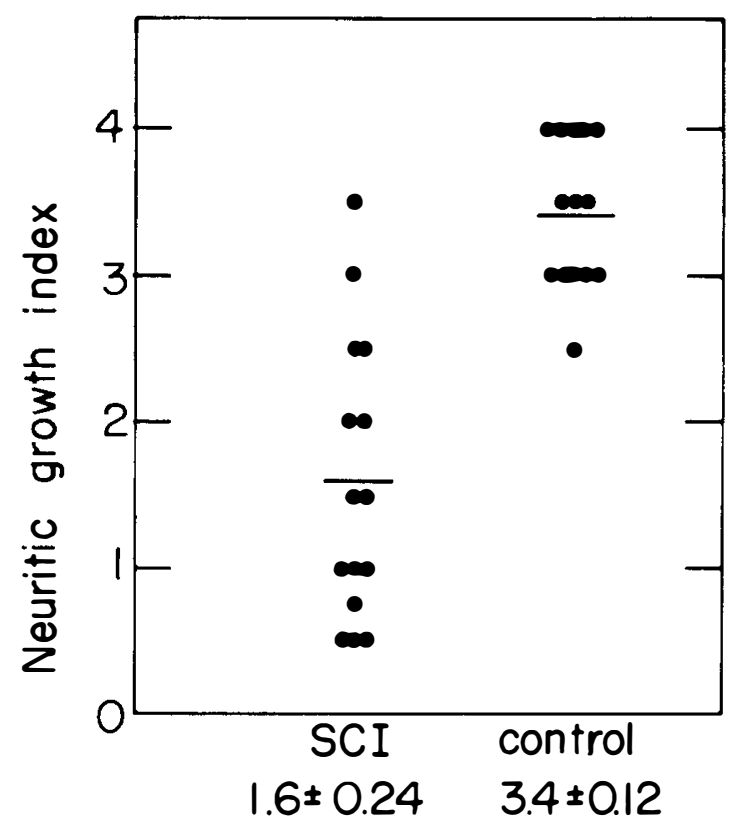

FIG. 3

The effect of sera derived from spinal cord injured patients (SCI) on sprouting induced from 9-day-old chick embryo DRG.

The results are expressed by the neuritic growth index (NGI) of the sprouting induced by the sera added to DMEM at a final concentration of ro per cent. Growth was scored 24 hrs following the culturing. Each column represents the distribution of the NGI obtained by the various individual sera tested. The mean \pm SEM is given at the bottom of each column. 
These observations have led us to propose that changes in serum components as a response to nerve injury may exert an effect on the ability to regenerate. Following spinal cord injury initial sprouting occurs and becomes abortive after a while. We have considered the possibility that the failure of the newly growing fibres to continue towards their target evolves either from deficiency in trophic material essential for growth, guidance or maintanance, or from the presence of inhibitory factors.

To test this possibility we have used an in vitro assay for determining trophic activity within the serum. In normal human sera components inducing sprouting have been described (Bill et al., I969) and confirmed by us too. In contrast, limited sprouting is supported by sera from spinal cord injured patients. Eighty per cent of these sera had limited sprouting activity or none at all. Since all the sera were taken from patients long after the injury, the time schedule for the changes in the sera with this respect could not be studied.

The changes in the ability of the patients to provide trophic environment for neurites could emerge from the loss of such substances or from the appearance of some growth-inhibitory factors. The appearance of autoantibodies in the spinal cord injured patients may relate to the low ability of their sera to support sprouting.

Antibodies against gangliosides have been demonstrated to inhibit sprouting induced by various trophic factors (Spirman et al., in press; Schwartz and Spirman, in press). Such antibodies may exert their effect either by interacting directly with the neuronal membrane gangliosides, thus preventing their accessibility to trophic factors, or by neutralising serum gangliosides which are endowed with the ability to support regeneration as was demonstrated lately (Gorio et al., I980).

In a recent study on idiopathic facial nerve paralysis (Bell's palsy) we demonstrated that the inhibitory effect of these sera on DRG is not due to a lack of trophic factors, but to the existence of inhibitory factors, which could be detected in the immunoglobulin fraction of the sera (Aviel and Schwartz, in press).

One should consider also the possibility that antibodies of other specificities such as those directed against other components of the myelin like myelin basic protein (MBP) are responsible for the inhibitory effect. Growth inhibitory factors other than those of immunoglobulin nature can not be ruled out at the moment, such as those described lately McConnell and Berry (1982).

The present study gives some indications of changes in humoral factors following spinal cord injury. The relevance of these findings to the in situ conditions has to be studied. However, knowing one of the impedances to nerve regeneration in the CNS may suggest a way to overcome it.

\section{RÉSUMÉ}

Les facteurs systémiques humoraux ont été étudiée chez les traumatisés médullaires choniques et aigus. Des anticorps spécifiques aux auto-antigènes du système nerveux ont été détectée dans la plupart des sérums prélevés chez les patients, à difféerentes périods après le traumatisme. Une croissance limitée in vitro de ganglions radicaux dorsaux chez des embryons de poussins eu présence du sérum de ces patients a été constatée. Nous examinons la possibilité d'une association entre des faceurs anti-croissance et la présence d'anticorps aux auto-antigènes du tissu nerveux. 


\section{ZUSAMMENFASSUNG}

Die systemischen Humoralfaktoren wurden bei chronischen und akuten Rückenmarkverletzten untersucht. Spezifische Abwehrstoffe gegen die auto-Antigene des Nervensystems wurden in den meisten Sera, die bei den Patienten zu verschiedene Zeitpunkten nach der Verletzung abgenommen wurden, refunden. Ein beschränktes in vitro Wachstum der Rückennervenwurzelknoten wurde bei Kuckenembryos in Anwesenheit des Serum dieser Patienten beobachtet. Wir besprechen die Möglichkeit einer Verbindung zwischen antiWachstum Faktoren und der Anwesenheit Abwehrstoffe gegen auto-Antigene des Nervengewebes.

\section{REFERENCES}

ANDo, S. \& YU, R. K. (1977). Isolation and characterization of a novel trisialoganglioside $\mathrm{GT}_{1 \mathrm{a}}$ from human brain. F. Biol. Chem., 252, 6247.

Aviel, A. \& SchwARTZ, M. Sprouting inducing activity of human sera: Low capacity in sera from patients with cranial poly neuropathy. F. Neurosci. Res., (in press).

BERRY, M. \& RicheS, A. C. (I974). An immunological approach to regeneration in the central nervous system. Br. Med. Bull., 30, I35.

Bill, H. A., Seibert, E. S., Bekwith, J. B. \& Hartman, J. R. (I969). Nerve growth factor and nerve growth-stimulating activity in sera from normal and neuroblastoma patients. F. Natl. Cancer Inst., 43, I 221.

Caspary, E. A. \& Chambers, M. E. (1970). Antibody to encephalitogenic basic protein in multiple sclerosis and other neurological diseases as measured by immune adherence. Europ. Neurol., 3, 206.

Cook, S. D. \& Dowling, P. C. (I98I). The role of autoantibody and immune complexes in the pathogenesis of Guillain-Barre syndrome. Ann. Neurol., 9 (suppl), 70.

DE LA TORRE, J. C. (I98I). Spinal cord injury: Review of basic and applied research. Spine, 6, 315.

Den, H., Sela, B., Roseman, S. \& Sachs, L. (1974). Blocks in gangliosides synthesis in transformed hamster cells and their revertance. 7 Biol, Chem., 29, 659.

Gorio, A., Carmignoto, G., Facci, L. \& Finesso, M. (I980). Motor nerve sprouting induced by ganglioside treatment: Possible implications for gangliosides on neuronal growth. Brain. Res., 197, 236.

Hirshfeld, H., Teitelbaum, D., Annon, R. \& Sella, M. (i970). Basic encephalitogenic protein: a simplified purification on sulphoethyl-sephadex. FEBS Lett., 7, 717.

HunTER, W. M. (1973). Radioimmunoassay, in: Handbook of Experimental Immunology, chapter 17. Oxford: Blackwell Scientific Publications.

KIERNAN, J. A. (I979). Hypotheses concerned with axonal regeneration in the mammalian nervous system. Biol. Rev., 54, I55.

LeVi-MONTALCINI, R. \& HAMBURGER, V. (I95I). Selective growth stimulating effects of mouse sarcoma on the sensory and sympathetic nervous syste, of the chick embryo. F. Exp. Zool., I16, 321 .

Levi-Montalcini, R. \& HAMburger, V. (I953). A diffusable agent of mouse sarcoma producing hyperplasia of sympathetic ganglia and hyperneurotization of chick embryo. F. Exp. Zool., 123, 233.

MCDONALD, W. I. (I975). Mechanisms of functional loss and recovery in spinal cord damage. Outcome of severe damage to the central nervous system. CIBA Foundation Symposium, 34, Amsterdam: Elsevier, pp. 23-29.

MCCONNELl, P. \& BERRY, M. (I982). Regeneration of ganglion cell axons in the adult mouse retina. Brain Res., $241,362$.

Śchwartz, M., Novik, D., Givol, D.\& Fūchs; S. (1978). Iñduction ó anti-idiotypic antibodies by immunization with syngeneic spleen cells educated with acetylcholine receptor. Nature, 273, 543.

SchwarTZ, M. \& SpIRMAN, N. (1982). Sprouting from chick embryo dorsal root ganglia induced by nerve growth factor is specifically inhibited by affinity purified anti- $\mathrm{G}_{\mathrm{MI}_{\mathrm{I}}}$ antibodies. Proc. Natl. Acad. Sci., 79, 6080.

Schwartz, M., Sela, B. A. \& Eshrar, N. (I982). Production of antibodies against autoantigens induced by peripheral nerve injury in mice. F. Neurochem., 38, I 192.

Spirman, N., Sela, B. A. \& Schwartz, M. (I982). Anti-ganglioside antibodies inhibit outgrowth from regenerating goldfish retinal explant. $\mathcal{F}$. Neurochem., 39, 874 .

VARON, S. \& ADLER, R. (I98I). Trophic and specifying factors directed to neuronal cells. Adv. Cell Neurobiol., 2, I I5. 